\title{
PENINGKATAN KEMAMPUAN BERBICARA TEKS HORTATORY EXPOSITION MENGGUNAKAN PROBLEM BASED LEARNING DENGAN PRESENTASI BERBANTUAN FILM
}

\author{
Lestari Ambar Sukesti \\ SMA Negeri 1 Bergas \\ Email: lestariambarsukesti@gmail.com
}

(Diterima: 4 Desember 2020; Direvisi: 11 Desember 2020; Publikasi: 31 Desember 2020)

\begin{abstract}
ABSTRAK
Penelitian ini bertujuan untuk meningkatkan keterampilan berbicara teks hortatory exposition peserta didik kelas XI.IPA.1 SMAN 1 Bergas melalui Problem Based Learning (PBL) dengan Presentasi Berbantuan Film. Penelitian ini adalah penelitian tindakan kelas selama dua siklus, yaitu Siklus I dan Siklus II yang masing-masing dilaksanakan dalam dua pertemuan. Subjek pada penelitian ini 32 peserta didik yang terdiri dari 23 perempuan dan 9 laki-laki. Teknik pengumpulan data dilakukan dengan tes performa, observasi, dan dokumen. Hasil yang diperoleh menunjukkan bahwa penggunaan PBL dengan presentasi berbantuan film dapat meningkatkan proses pembelajaran pada siklus I sedangkan pada siklus II proses pembelajaran meningkat dengan sangat baik. Hasil tes keterampilan berbicara pada siklus I cukup baik sedangkan pada siklus II meningkat menjadi kategori baik. Perubahan tingkah laku yang berupa sikap berpikir kritis cukup baik pada siklus I dan meningkat menjadi baik pada siklus II demikian pula dengan kreativitas peserta didik cukup baik pada siklus I dan meningkat menjadi baik pada siklus II. Hasil tersebut menunjukkan bahwa penggunaan PBL dengan presentasi berbantuan film dapat meningkatkan proses pembelajaran teks hortatory exposition, kemampuan berbicara, dan perilaku peserta didik. Rekomendasi peningkatkan efektifitas penggunaan PBL dengan presentasi berbantuan film yaitu dengan melakukan sesi tanya jawab yang dipimpin oleh seorang moderator.
\end{abstract}

Kata kunci: Kemampuan berbicara; Presentasi berbantuan film; Problem Based Learning; Teks hortatory exposition

\section{ABSTRACT}

This study aims to improve the speaking skills of students of class XI.IPA.1 SMAN 1 Bergas on hortatory exposition text through Problem Based Learning (PBL) by using film assisted presentations. This research is a classroom action research conducted in two cycles, namely cycle I and cycle II, each of which was conducted in two meetings. The subjects of this study were 32 students consisting of 23 girls and 9 boys. The data is taken by using performance tests, observations, and documents. The results obtained indicate that the use of PBL by using film-assisted presentations can improve the learning process in cycle I, while in cycle II the learning process increases very well. The speaking skill test result in cycle I was in quite good category, while in cycle II it increased into good category. Behavioral changes in the form of critical thinking were good enough in cycle I while in cycle II were good as well as

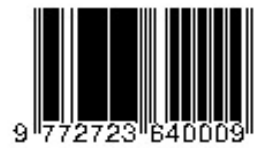


Lestari Ambar Sukesti

Peningkatan Kemampuan Berbicara Teks Hortatory Exposition Menggunakan Problem Based Learning Dengan

Presentasi Berbantuan Film

students' creativity that was good enough in cycle I and good in cycle II. These results indicate that the use of PBL by using film-assisted presentations can improve the learning process of hortatory exposition text, speaking skills, and student behavior. To increase the effectiveness of PBL by using film-assisted presentations it is recommended to conduct a question and answer session led by a moderator.

Keywords: Film assisted presentation; Hortatory exposition texts; Problem Based Learning; Speaking Ability

\section{PENDAHULUAN}

Pembelajaran bahasa Inggris bertujuan untuk meningkatkan empat kemampuan berbahasa yang meliputi kemampuan produktif yang meliputi speaking dan writing serta kemampuan reseptif yang meliputi listening dan reading (Tarigan: 2008). Kemampuan berbahasa untuk berkomunikasi ini merupakan bagian pembelajaran di abad ke-21 yang perlu dikembangkan sebagai salah satu upaya meningkatkan kemampuan peserta didik di kancah pergaulan dunia. Teks Hortatory Exposition adalah salah satu teks yang memiliki tujuan komunikasi untuk mempengaruhi dan membujuk pendengar atau pembaca tentang sesuatu kasus serta memberikan saran terhadap kasus tersebut sehingga pada peserta didik diperlukan sebuah sikap yaitu berpikir kritis (Dereiwanka: 1995).

Namun kenyataannya di lapangan peserta didik belum sepenuhnya memiliki kemampuan berpikir kritis untuk menemukan masalah dan solusi atas sesuatu masalah tersebut yang kemudian dituangkan dalam kegiatan berbicara. Hal ini disebabkan pembelajaran di kelas yang kurang menitikberatkan pada praktik berbicara. Kesulitan peserta didik dalam mengajukan ide atau gagasan untuk melakukan kegiatan berbicara ditambah dengan faktor takut salah, takut ditertawakan, malu dan kurangnya kosakata juga berpengaruh terhadap rendahnya keterampilan berbicara. Pencapaian nilai KKM 70 dari 32 peserta didik hanya sebesar $42 \%$ sedangkan nilai di bawah 70 mencapai $58 \%$.

Fenomena di atas merupakan salah satu tantangan yang harus dihadapi oleh guru pengampu bahasa Inggris yaitu bagaimana cara meningkatkan kemampuan berbicara pada teks hortatory exposition. Untuk membelajarkan materi teks hortatory exposition dengan efektif diperlukan kemampuan guru dalam metode pembelajaran sebagai salah satu kompetensi yang tidak dapat diabaikan dalam kegiatan pembelajaran (Wahab, 2007).

Penggunaan film telah terbukti efektif dalam membelajarkan kemampuan berbicara pada teks hortatory exposition (Mukaromah, 2011). Penggunaan PBL kebanyakan hanya untuk meningkatkan kemampuan berbicara (Hauroni, 2015; Devie, 2015). Selain itu penggunaan 
Lestari Ambar Sukesti

Peningkatan Kemampuan Berbicara Teks Hortatory Exposition Menggunakan Problem Based Learning Dengan

Presentasi Berbantuan Film

audio visual yang di dalamnya memuat presentasi berbantuan film hanya digunakan oleh guru untuk menyampaikan materi dalam proses pembelajaran (Wahyuningsih, Mujiman, Haryanto, 2014).

Namun dalam penelitian ini penggunaan PBL dikombinasikan dengan presentasi berbantuan film untuk meningkatkan kemampuan berbicara peserta didik. Model pembelajaran PBL dengan presentasi berbantuan film ini diduga dapat meningkatkan kemampuan berbicara peserta didik pada teks hortatory exposition.

\section{KAJIAN PUSTAKA}

\section{Hakikat Berbicara}

Berbicara adalah kemampuan mengucapkan bunyi-bunyi artikulasi atau kata-kata untuk mengekspresikan, menyatakan serta menyampaikan pikiran, gagasan, dan perasaan baik bersifat konsepsional maupun prosedural (Tarigan, 2008; Ellis, 2008; Iskandarwassid, dkk: 2010; Ningsih, 2007).

Berbicara juga merupakan aktifitas berbahasa kedua yang dilakukan manusia dalam kehidupan berbahasa, yaitu aktifitas setelah mendengarkan. Artinya bahwa ada aktivitas yang mendasari sebuah kegiatan berbicara (Nurgiyantoro: 2001; Murcia: 2000). Berbicara menjadi hal yang penting karena melibatkan pemahaman dari lawan bicara terkait dengan kelancaran dan kecepatan menjawab dan mempertahankan kelangsungan pembicaraan (Thornburry: 1990). Sedangkan Yule (1996) mengategorikan kegiatan berbicara sebagai bentuk komunikasi paling mudah yang dapat dilakukan oleh manusia ini menjadi dua yaitu: 1) kategori fungsi transaksional dan 2) kategori fungsi interaksional. Fungsi transaksional mementingkan transfer informasi sedangkan fungsi interaksional mementingkan fakta bahwa kegunaan utama ujaran adalah mempertahankan hubungan sosial.

\section{Teks Hortatory Exposition}

Teks Hortatory Exposition adalah jenis teks yang menyajikan argumen atau alasan untuk mendukung pendapat. Teks Hortatory Exposition ini bertujuan untuk memengaruhi pembaca atau pendengar bahwa sesuatu topik itu merupakan kasus dan penting sehingga perlu diberikan saran terhadap kasus yang diperbincangkan tadi. Teks ini memiliki struktur teks yang berupa thesis, arguments, dan recommendation.

Thesis menyatakan posisi pembicara, sedangkan arguments merupakan pendapat yang melatarbelakangi pembicara meyampaikan thesis atau pokok permasalahannya, sedangkan rcommendation adalah saran yang diberikan oleh pembicara sehubungan dengan kasus atau masalah yang dibawakannya (Gerot and Wignell, 1994). 
Lestari Ambar Sukesti

Peningkatan Kemampuan Berbicara Teks Hortatory Exposition Menggunakan Problem Based Learning Dengan

Presentasi Berbantuan Film

\section{Problem Based Learning}

Problem Based Learning (PBL) merupakan model pembelajaran yang menitikberatkan pada pemecahan masalah nyata yang terjadi dalam kehidupan sehari-hari. Dengan model pembelajaran ini peserta didik tertantang untuk belajar dan termotivasi serta terlibat aktif dalam pembelajaran. Selain itu peserta didik akan berlatih untuk mengembangkan keterampilan berfikir kritis. Model pembelajaran PBL ini mengikuti kaidah atau sintak pembelajaran tertentu (Kemdikbud, 2014).

Tabel 1. Tahapan-tahapan Model PBL

\begin{tabular}{ll}
\hline \multicolumn{1}{c}{ Fase-fase } & \multicolumn{1}{c}{ Perilaku Guru } \\
\hline Fase 1 & Menjelaskan tujuan pembelajaran, menjelaskan logistik \\
Orientasi peserta didik kepada & yang dibutuhkan \\
masalah & Memotivasi peserta didik untuk terlibat aktif dalam \\
& pemecahan masalah yang dipilih. \\
Fase 2 & Membantu peserta didik mendefinisikan dan \\
Mengorganisasikan peserta didik & mengorganisasikan tugas belajar yang berhubungan \\
& dengan masalah tersebut. \\
Fase 3 & Mendorong peserta didik untuk mnegumpulkan \\
Membimbing penyelidikan individu & informasi yang sesuai; melaksanakan eksperimen untuk \\
dan kelompok & mendapatkan penjelasan dan pemecahan masalah. \\
Fase 4 & Membantu peserta didik dalam merencanakan dan \\
Mengembangkan dan menyajikan & meyiapkan karya yang sesuai seperti laporan, model, dan \\
hasil karya & berbagi tugas dengan teman. \\
Fase 5 & Mengevaluasi hasil belajar tentang materi yang telah \\
Menganalisa dan mengevaluasi proses & dipelajari dan meminta kelompok presentasi hasil kerja. \\
pemecahan masalah &
\end{tabular}

(Sumber: Kemdikbud, 2014: 40-42)

\section{Presentasi Berbantuan Film}

Presentasi adalah sebentuk komunikasi yang dilakukan secara terpadu, lewat suara, gambar, bahasa tubuh, dan penggunaaan media untuk menyampaikan ide dan informasi (Noer, 2012; Sutomo, 2007; Tri Wahyuni dan Kadir, 2004). Pada penelitian ini presentasi digunakan sebagai alat bantu atau media bagi para peserta didik untuk mengemukakan pendapatnya. Sedangkan media yang digunakan adalah media power point dengan slide-slide yang dilengkapi dengan film tentang masalah sosial. Masalah ini adalah masalah yang diperoleh peserta didik melalui 
Lestari Ambar Sukesti

Peningkatan Kemampuan Berbicara Teks Hortatory Exposition Menggunakan Problem Based Learning Dengan Presentasi Berbantuan Film

diskusi kelompok yang dilanjutkan dengan mencari solusi dari permasalahan yang timbul tersebut.

Film ini bisa diunduh dari internet atau dengan cara membuat sendiri sesuai dengan masalah yang disampaikan kemudian diselipkan pada presentasi power point. Tujuannya adalah agar film ini dapat membantu peserta didik dalam menyampaikan ide maupun gagasannya mengenai masalah sosial yang terjadi baik secara umum maupun khusus yang terjadi di lingkup sekolah mereka.

\section{PBL dalam Peningkatan Kemampuan Berbicara}

PBL merupakan suatu kegiatan pembelajaran yang menekankan pada proses penyelesaian masalah yang dialami di dunia nyata (Sanjaya, 2007; Triyanto, 2007). Dalam proses penyelesaian masalah peserta didik akan menyampaikan pendapatnya dalam kelompok terutama pada saat mencari solusi atas permasalahan yang dihadapi. Hal ini dapat melatih kemampuan berbicara peserta didik.

Masalah yang diangkat dalam PBL lebih bersifat terbuka yang berarti bahwa jawaban atas masalah ini belum pasti sehingga peserta didik dapat mengembangkan berbagai macam kemungkinan jawaban. Peserta didik dapat lebih mengeksplorasi, mengumpulkan data, dan menganalisis data secara lengkap untuk memecahkan masalah yang dihadapi.

\section{METODE PENELITIAN}

Penelitian ini merupakan penelitian tindakan kelas menggunakan dua siklus yaitu siklus I dan siklus II. Masing-masing siklus yang terdiri atas dua pertemuan ini melalui prosedur penelitian yang terdiri atas empat tahap yaitu: 1) perencanaan, 2) tindakan, 3) pengamatan, dan 4) refleksi (Arikunto, 2010).

Subjek pada penelitian ini adalah keterampilan berbicara teks hortatory exposition dengan model pembelajaran PBL menggunakan presentasi berbantuan film pada peserta didik kelas XI. Sumber data adalah kelas XI. MIPA. 1 tahun 2017/2018 semester 1 yang berjumlah 32 dengan komposisi 9 peserta didik putra dan 23 peserta didik putri.

Instrumen yang digunakan dalam penelitian ini adalah instrumen tes dan nontes. Instrumen tes digunakan untuk mengungkapkan data peningkatan pengetahuan dan keterampilan berbicara secara kuantitatif. Sementara instrumen non-tes digunakan untuk mengetahui proses pembelajaran dan perubahan perilaku yaitu menghargai pendapat orang lain, bekerja sama, mengemukakan pendapat, dan mau bertanya.

Prosedur dari penelitian ini adalah: 1) tahap persiapan, kegiatan pada tahap ini adalah menyusun rencana pembelajaran keterampilan berbicara menggunakan model PBL dengan 
Lestari Ambar Sukesti

Peningkatan Kemampuan Berbicara Teks Hortatory Exposition Menggunakan Problem Based Learning Dengan Presentasi Berbantuan Film

presentasi berbantuan film, menyiapkan materi pembelajaran yang relevan, menyiapkan instrumen baik tes maupun nontes, 2) tahap pelaksanaan, kegiatan pada tahap ini adalah melaksanakan pembelajaran kemampuan berbicara menggunakan PBL dengan presentasi berbantuan film, melakukan pengamatan, melakukan post test dalam bentuk tes unjuk kerja kemampuan berbicara, 3) tahap refleksi, yaitu memeriksa semua dokumen yang terkumpul lalu mengidentifikasi masalah yang timbul yang menyebabkan kurang optimalnya hasil di siklus I kemudian menyusun langkah perbaikan di siklus II.

\section{HASIL PENELITIAN}

Pembelajaran keterampilan berbicara pada teks hortatory exposition dengan presentasi berbantuan film dilakukan sesuai dengan sintak model pembelajaran PBL sebagai berikut:

Langkah pertama: Guru memutar film tentang masalah dalam kehidupan kita sehari-hari. Peserta didik diminta untuk mengidentifikasi apa yang terjadi, apa yang menyebabkan masalah dan bagaimana masalah itu bisa terjadi lalu saran apa yang dapat diberikan.

Langkah kedua: Guru meminta peserta didik untuk membuat kelompok yang terdiri dari 4 atau 5 orang. Peserta didik diminta untuk berdiskusi dan berbagi ide kepada anggota kelompok.

Langkah ketiga: Peserta didik mengumpulkan informasi dengan cara menyelidiki dan menemukan data dari sumber apa pun tentang masalah yang mereka hadapi.

Langkah keempat: Peserta didik bekerja bersama dalam kelompok untuk merancang, membagikan gagasan mereka dan kemudian mendiskusikan pembuatan presentasi berbantuan film serta teks hortatory exposition berkenaan dengan masalah yang telah ditemukannya.

Langkah kelima: Peserta didik diminta untuk mempresentasikan hasil diskusi mereka yang berupa teks hortatory exposition dengan menggunakan presentasi berbantuan film hasil karya mereka.

Langkah keenam: Guru dan peserta didik melakukan refleksi dari seluruh kegiatan yang telah dilakukan.

Hasil penelitian tindakan kelas ini, diperoleh dari tindakan siklus I dan tindakan siklus II. Hasil tes siklus I dan siklus II berupa tes tertulis dan tes unjuk kerja berbicara. Tes tertulis digunakan untuk mengetahui pengetahuan peserta didik tentang materi teks hortatory exposition sedangkan tes unjuk kerja berbicara untuk mengetahui keterampilan berbicara peserta didik dengan model pembelajaran Problem Based Learning menggunakan presentasi berbantuan film.

Hasil nontes siklus I dan siklus II diperoleh melalui observasi, jurnal guru, jurnal peserta didik, wawancara, dan dokumentasi foto. Hasil tersebut berupa proses pembelajaran 
Lestari Ambar Sukesti

Peningkatan Kemampuan Berbicara Teks Hortatory Exposition Menggunakan Problem Based Learning Dengan Presentasi Berbantuan Film

peningkatan keterampilan berbicara menggunakan model pembelajaran PBL dengan presentasi berbantuan film, perubahan perilaku berpikir kritis, peningkatan pengetahuan mengenai teks hortatory exposition, peningkatan kreativitas, dan peningkatan keterampilan berbicara teks hortatory exposition. Hasil penelitian siklus I dan siklus II dijabarkan sebagai berikut.

\section{SIKLUS I}

Proses pembelajaran yang hendak dicapai dalam pembelajaran keterampilan berbicara pada teks hortatory exposition menggunakan model pembelajaran PBL dengan presentasi berbantuan film yaitu: 1) antusiasme dan minat peserta didik; 2) pelaksanaan diskusi kelompok yang kondusif untuk mengidentifikasi karakteristik dan fitur linguistik dari teks; 3 ) intensitas diskusi kelompok selama pelajaran; 4) intensitas pelaksanaan praktik berbicara yang dilakukan oleh peserta didik dalam kelompok; 5) refleksi kegiatan di akhir pembelajaran sehingga peserta didik mengetahui kekurangan dan apa yang akan dilakukan selanjutnya.

Pada siklus I masalah yang diangkat adalah tentang masalah umum yang terjadi seperti kemacetan, banjir, kemiskinan, dll. Guru membuat kelompok sesuai dengan tempat duduk peserta didik. Peserta didik yang duduknya berdekatan dijadikan satu kelompok. Hasil yang dicapai menunjukkan untuk aspek pertama yaitu antusiasme dan minat peserta didik terdapat 26 peserta didik yang memperhatikan atau setara dengan $81 \%$ dan termasuk dalam kategori baik. Aspek yang kedua yaitu kondusifnya diskusi kelompok dalam mengidentifikasi karakteristik dan fitur linguistik, terdapat 25 peserta didik yang memperhatikan atau sekitar 78\% dan termasuk dalam kategori baik. Aspek ketiga yaitu intensitas diskusi kelompok selama pembelajaran, terdapat 22 peserta didik yang memperhatikan atau sekitar $69 \%$ dan termasuk dalam kategori cukup. Aspek keempat yaitu intensitas dari praktik berbicara dalam kelompok terdapat 23 peserta didik yang memperhatikan atau $72 \%$ dan termasuk dalam kategori cukup. Aspek kelima yaitu refleksi di akhir pembelajaran sehingga peserta didik mengetahui kekurangan dan apa yang akan dilakukan selanjutnya, ada 26 peserta didik yang memperhatikan atau berjumlah $81 \%$ dan termasuk dalam kategori baik. Secara keseluruhan hasil proses pembelajaran pada siklus ini memiliki rerata 76,2 dan termasuk dalam kategori baik.

Hasil perilaku berpikir kritis peserta didik pada siklus I, diidentifikasi dari sikap berpikir kritis peserta didik ketika mengikuti pembelajaran keterampilan berbicara. Hasil sikap berpikir kritis peserta didik merupakan hasil nontes siklus I yang diperoleh melalui penilaian observasi sikap berpikir kritis dan jurnal guru. Penilaian observasi sikap berpikir kritis 
Lestari Ambar Sukesti

Peningkatan Kemampuan Berbicara Teks Hortatory Exposition Menggunakan Problem Based Learning Dengan Presentasi Berbantuan Film

mencakup empat indikator, yaitu: 1) memberikan sumbangan ide; 2) mendefinisikan sebuah batasan; 3) mengklarifikasi makna; dan 4) berinteraksi dengan orang lain.

Pada siklus I guru menyampaikan tema yang harus didiskusikan adalah masalah secara umum, misalnya pendidikan, sosial, ekonomi, dan budaya. Peserta didik diberikan kebebasan untuk menyampaikan pendapatnya mengenai masalah yang dihadapi dalam kehidupan bernegara maupun dunia. Dari penilaian observasi sikap berpikir kritis peserta didik dalam mengikuti pembelajaran keterampilan berbicara teks hortatory exposition menggunakan model pembelajaran PBL dengan presentasi berbantuan film pada siklus I diperolah hasil sebagai berikut. Terdapat 4 peserta didik memperoleh rentang nilai 80-100 atau termasuk dalam kategori sangat baik, 18 peserta didik atau sebesar 68,75 \% memperoleh rentang nilai 70-100 atau termasuk dalam kategori baik. Sedangkan rerata nilai sikap berpikir kritis peserta didik mencapai 67,59 atau termasuk berkategori cukup.

Aspek penilaian memberikan sumbangan ide dan berinteraksi dengan orang lain sudah baik namun untuk aspek mendefinisikan sebuah batasan dan mengklarifikasi makna masih termasuk dalam kategori cukup. Hasil keterampilan berbicara diperoleh dari tes unjuk kerja yang berupa tes berbicara secara berkolaborasi. Penilaian keterampilan berbicara peserta didik berdasarkan aspek-aspek penilaian keterampilan berbicara yang meliputi: 1) pengucapan;2) tata bahasa; 3) kosa kata; 4) kelancaran; dan 5) pemahaman.

Dari penilaian diperoleh rerata nilai peserta didik sebesar 69,43 yang termasuk dalam kategori cukup sedangkan prosentase peserta didik yang sudah mencapai KKM 70 sebesar 65,51\%. Terdapat empat peserta didik yang memperoleh nilai berkategori sangat baik, 18 peserta didik memperoleh nilai berkategori baik, sedangkan 5 peserta didik mencapai kategori cukup dan 5 peserta didik mencapai kategori kurang.

Dari aspek penilaian keterampilan berbicara untuk aspek tata bahasa, dan kosa kata sudah mencapai kategori baik sedangkan aspek pengucapan, pemahaman, dan kelancaran masih dalam kategori cukup. Kreativitas peserta didik dalam keterampilan berbicara diperoleh dari produk presentasi berbantuan film dan teks hortatory exposition secara berkolaborasi. Penilaian produk dari peserta didik berdasarkan aspek-aspek penilaian produk meliputi: 1) bentuk fisik; 2) isi; 3) kreativitas; dan 4) kelancaran.

Pada siklus I peserta didik belum maksimal dalam berkreativitas membuat produk berupa presentasi berbantuan film dan teks hortatory exposition. Hal tersebut terlihat dari rerata nilai yang diperoleh peserta didik pada aspek ini mencapai kategori baik, yaitu 70,25. Namun demikian hanya terdapat empat peserta didik yang memperoleh skor berkategori sangat baik. 
Lestari Ambar Sukesti

Peningkatan Kemampuan Berbicara Teks Hortatory Exposition Menggunakan Problem Based Learning Dengan Presentasi Berbantuan Film

Sebanyak 12 peserta didik atau 37,5\% memperoleh skor berkategori baik dan enam belas peserta didik atau sebesar 50\% memperoleh skor berkategori cukup.

\section{SIKLUS II}

Pada siklus II kegiatan pembelajaran ditekankan pada aspek yang masih tergolong cukup yaitu pada aspek ketiga dan keempat. Dengan melakukan perubahan anggota kelompok yaitu dengan cara berhitung dari angka 1 hingga 8 dan penyederhanaan masalah yang diangkat ternyata mampu meningkatkan proses pembelajaran.

Dari hasil observasi penilaian pada aspek kesatu yaitu antusiasme dan minat peserta didik terhadap proses pembelajaran terdapat 32 peserta didik yang memperhatikan atau sebanyak $100 \%$ dan termasuk dalam kategori sangat baik. Aspek kedua yaitu diskusi kelompok yang kondusif dalam mengidentifikasi karakteristik dan fitur linguistik terdapat 28 peserta didik yang memperhatikan atau sebanyak $88 \%$ dan termasuk dalam kategori sangat baik. Aspek ketiga yaitu intensitas diskusi kelompok selama pembelajaran terdapat 27 peserta didik yang memperhatikan atau sekitar $87 \%$ dan termasuk dalam kategori sangat baik. Aspek keempat yaitu intensitas pelaksanaan praktik berbicara dalam kelompok terdapat 27 peserta didik yang memperhatikan atau sama dengan $87 \%$ dan termasuk dalam kategori sangat baik. Aspek kelima yaitu reflektifitas dari kegiatan refleksi di akhir pembelajaran sehingga peserta didik mengetahui kekurangan dan apa yang akan dilakukan selanjutnya, ada 25 peserta didik yang memperhatikan atau sebesar $80 \%$ dan termasuk dalam kategori sangat baik.

Hasil pengamatan perilaku berpikir kritis dan kreatif peserta didik pada siklus II mengalami peningkatan. Hal ini dikarenakan masalah yang diangkat sangat dekat dengan kehidupan mereka sebagai peserta didik di sekolah. Dari penilaian observasi sikap berpikir kritis dan kreatif peserta didik pada siklus II diperolah hasil sebagai berikut. Terdapat 8 peserta didik memperoleh rentang nilai 80-100 atau termasuk dalam kategori sangat baik, 24 peserta didik atau sebesar 75\% memperoleh rentang nilai 70-100 atau termasuk dalam kategori baik. Sedangkan rerata nilai sikap berpikir kritis peserta didik mencapai 74,5 atau termasuk berkategori baik.

Hasil keterampilan berbicara pada siklus II diperoleh rerata nilai peserta didik sebesar 76,12 yang termasuk dalam kategori baik dan semua peserta didik sudah mencapai KKM 70. Terdapat delapan peserta didik yang memperoleh nilai berkategori sangat baik, 24 peserta didik memperoleh nilai berkategori baik dan tidak ada peserta didik mencapai kategori cukup atau kurang.

Pada siklus II peserta didik sudah baik dalam berkreativitas membuat produk berupa presentasi berbantuan film dan teks hortatory exposition. Hal tersebut terlihat dari rerata nilai 
Lestari Ambar Sukesti

Peningkatan Kemampuan Berbicara Teks Hortatory Exposition Menggunakan Problem Based Learning Dengan Presentasi Berbantuan Film

yang diperoleh peserta didik pada aspek ini mencapai kategori baik, yaitu 78,25. Terdapat delapan peserta didik yang memperoleh skor berkategori sangat baik. Sebanyak 24 peserta didik atau $75 \%$ memperoleh skor berkategori baik dan tidak ada peserta didik yang memperoleh skor berkategori cukup atau kurang.

Berdasarkan hasil penelitian yang telah dilakukan selama dua siklus, diketahui terjadi peningkatan yang signifikan dan memuaskan dari siklus I ke siklus II. Pada proses pembelajaran peningkatan keterampilan berbicara mengalami peningkatan pada tiap-tiap aspek. Aspek keantusiasan dan minat jumlah peserta didik mengalami peningkatan dari 28 peserta didik di siklus I meningkat menjadi 32 peserta didik di siklus II. Aspek kekondusifan pelaksanaan diskusi kelompok mengidentifikasi karakteristik dan unsur kebahasaan teks hortatory exposition mengalami jumlah peningkatan 25 peserta didik di siklus I menjadi 28 peserta didik di siklus II. Aspek keintensifan pelaksanaan diskusi kelompok setelah menyimak tayangan masalah terjadi peningkatan jumlah dari 22 peserta didik di siklus I menjadi 24 peserta didik di siklus II. Aspek keintensifan pelaksanaan praktik berbicara yang dilakukan peserta didik dalam kelompok terjadi peningkatan dari 23 peserta didik di siklus I menjadi 26 peserta didik di siklus II. Aspek reflektifitas kegiatan refleksi pada akhir pembelajaran sehingga peserta didik mengetahui kekurangan ada apa yang akan dilakukan selanjutnya mengalami peningkatan dari jumlah 26 peserta didik di siklus I menjadi 30 peserta didik di siklus II.

Tabel 2. Peningkatan Proses Pembelajaran

\begin{tabular}{|c|c|c|c|c|c|}
\hline \multirow{2}{*}{ No } & \multirow{2}{*}{ Aspek } & \multicolumn{2}{|c|}{ Siklus } & \multicolumn{2}{|c|}{ Prosentase } \\
\hline & & I & II & I & II \\
\hline 1 & keantusiasan dan minat peserta didik terhadap pembelajaran & 26 & 32 & 81 & 100 \\
\hline 2 & keterampilan berbicara & 25 & 28 & 78 & 88 \\
\hline 3 & $\begin{array}{l}\text { kekondusifan pelaksanaan diskusi kelompok mengidentifikasi } \\
\text { karakteristik dan fitur kebahasaan } \\
\text { keintensifan pelaksanaan diskusi kelompok setelah menyimak } \\
\text { tayangan materi pembelajaran }\end{array}$ & 22 & 24 & 69 & 78 \\
\hline 4 & $\begin{array}{l}\text { keintensifan pelaksanaan praktik berbicara yang dilakukan } \\
\text { peserta didik dalam kelompok }\end{array}$ & 23 & 26 & 72 & 81 \\
\hline 5 & $\begin{array}{l}\text { reflektifitas kegiatan refleksi pada akhir pembelajaran } \\
\text { sehingga peserta didik mengetahui kekurangan dan apa yang } \\
\text { akan dilakukan selanjutnya }\end{array}$ & 26 & 30 & 81 & 94 \\
\hline
\end{tabular}


Lestari Ambar Sukesti

Peningkatan Kemampuan Berbicara Teks Hortatory Exposition Menggunakan Problem Based Learning Dengan

Presentasi Berbantuan Film

Tabel 2 menunjukkan peningkatan masing-masing aspek proses pembelajaran. Pada aspek keantusiasan dan minat peserta didik terhadap pembelajaran keterampilan berbicara terdapat peningkatan sebesar 19\%, aspek kekondusifan pelaksanaan diskusi kelompok mengidentifikasi karakteristik dan fitur kebahasaan sebesar 10\%, aspek keintensifan pelaksanaan diskusi kelompok setelah menyimak tayangan materi pembelajaran sebesar $9 \%$, aspek keintensifan pelaksanaan praktik berbicara yang dilakukan peserta didik dalam kelompok sebesar $9 \%$, dan aspek reflektifitas kegiatan refleksi pada akhir pembelajaran sehingga peserta didik mengetahui kekurangan dan apa yang akan dilakukan selanjutnya sebesar $13 \%$. Secara keseluruhan terjadi peningkatan dari rerata di siklus I yaitu dari sebesar 76,2 yang merupakan kategori baik menjadi rerata sebesar 88,2 di siklus II dan merupakan kategori sangat baik.

Dari data hasil observasi proses peningkatan pembelajaran keterampilan berbicara tersebut, dapat disimpulkan bahwa proses pembelajaran mengalami peningkatan sebesar $12 \%$. setelah dilakukan perbaikan tindakan pada siklus II.

Pada keterampilan berbicara, nilai rerata tes keterampilan berbicara pada siklus II mengalami peningkatan dibandingkan nilai rerata tes keterampilan berbicara pada siklus I. Rerata tes keterampilan berbicara siklus II mengalami peningkatan sebesar 6,69 \% dari 69,43 pada siklus I menjadi 76,12 pada siklus II. Pada siklus II juga mengalami peningkatan pada tingkat ketuntasan, dari $68,75 \%$ pada siklus I menjadi $100 \%$ pada siklus II dan sudah memenuhi target ketuntasan penelitian. Dari hasil tes keterampilan menulis tersebut, dapat disimpulkan bahwa penggunaan model pembelajaran PBL dengan presentasi berbantuan film dapat meningkatkan keterampilan berbicara peserta didik.

Tabel 3. Peningkatan Kemampuan Berbicara

\begin{tabular}{llccccccccc}
\hline \multirow{2}{*}{ No } & \multirow{2}{*}{ Kategori } & Rentang & \multicolumn{2}{c}{ F } & \multicolumn{2}{c}{ Skor } & \multicolumn{2}{c}{ Persentase (\%) } & \multicolumn{2}{c}{ Rerata Nilai } \\
\cline { 3 - 10 } & Nilai & SI & SII & SI & SII & SI & SII & SI & SII \\
\hline 1 & Sangat Baik & $80-100$ & 4 & 8 & 330 & 336 & 12,5 & 25 & 69,43 & 76,12 \\
2 & Baik & $70-79$ & 18 & 24 & 1260 & 2100 & 56,25 & 75 & & \\
3 & Cukup & $60-69$ & 5 & & 332 & & 15,5 & & (Cukup) & (Baik) \\
4 & Kurang & $<60$ & 5 & & 290 & & 15,5 & & & \\
\hline Jumlah & & 32 & 32 & 2212 & 2436 & $100 \%$ & $100 \%$ & & \\
\hline
\end{tabular}


Lestari Ambar Sukesti

Peningkatan Kemampuan Berbicara Teks Hortatory Exposition Menggunakan Problem Based Learning Dengan Presentasi Berbantuan Film

Tabel 3 menunjukkan prosentase peserta didik yang mendapat nilai dalam kategori sangat bagus (80-100) juga mengalami peningkatan sebesar $12,5 \%$ atau meningkat $100 \%$ dari siklus I yaitu dari 4 orang meningkat jumlahnya menjadi 8 orang pada siklus II, sedangkan peserta didik yang mendapat nilai kurang maupun cukup juga tidak ada pada siklus II. Seluruh peserta didik sejumlah 32 mencapai nilai KKM 70.

Sikap berpikir kritis juga mengalami peningkatan. Hasil penilaian observasi sikap berpikir kritis dan kreatif siklus II mengalami peningkatan dibandingkan siklus I. Pelaksanaan pembelajaran keterampilan berbicara menggunakan PBL dengan presentasi berbantuan film dapat meningkatkan sikap berpikir kritis dan kreatif pada peserta didik.

Tabel 4. Peningkatan Hasil Penilaian Sikap Berpikir Kritis dan Kreatif

\begin{tabular}{llccccccccc}
\hline \multirow{2}{*}{ No } & Kategori & Rentang & \multicolumn{2}{c}{ F } & \multicolumn{2}{c}{ Skor } & \multicolumn{2}{c}{ Persentase (\%) } & \multicolumn{2}{c}{ Rerata Nilai } \\
\cline { 3 - 10 } & Nilai & SI & SII & SI & SII & SI & SII & SI & SII \\
\hline 1 & Sangat Baik & $80-100$ & 4 & 8 & 331 & 336 & 13,79 & 25 & 67,59 & 74,5 \\
2 & Baik & $70-79$ & 18 & 24 & 1323 & 2048 & 61,17 & 75 & & \\
3 & Cukup & $60-69$ & 10 & & 509 & & 23,53 & & (Cukup) & (Baik) \\
4 & Kurang & $<60$ & & & & & & & & \\
\hline Jumlah & & 32 & 32 & 2163 & 2384 & $100 \%$ & & & \\
\hline
\end{tabular}

Tabel 4 menunjukkan peningkatan rerata nilai, maupun prosentase jumlah peserta didik yang berhasil mencapai nilai KKM sebesar 70. Dari siklus I ke siklus II jumlah peserta didik yang memperoleh nilai yang sangat baik mengalami peningkatan dari sejumlah 4 peserta didik menjadi 8 atau sejumlah 11,21\%. Pada siklus I masih ada sejumlah 10 peserta didik yang mendapatkan nilai kurang sedangkan pada siklus II sudah tidak ada dan sebaliknya peserta didik yang memperoleh nilai baik sejumlah 28 peserta didik atau mengalami peningkatan sebesar 13,83\%. Peningkatan juga terjadi pada nilai rerata dari siklus I ke siklus II yaitu sebesar $6,91 \%$ dari 67,59 pada siklus I menjadi 74,5 pada siklus II.

Tabel 5. Peningkatan Kreativitas

\begin{tabular}{cccccccccccc}
\hline \multirow{2}{*}{ No } & Kategori & Rentang & \multicolumn{2}{c}{ F } & \multicolumn{2}{c}{ Skor } & \multicolumn{2}{c}{ Persentase (\%) } & \multicolumn{2}{c}{ Rerata Nilai } \\
\cline { 3 - 10 } & & Nilai & SI & SII & SI & SII & SI & SII & SI & SII \\
\hline 1 & Sangat Baik & $80-100$ & 4 & 8 & 324 & 680 & 12,5 & 25 & 69,12 & 78,25 \\
2 & Baik & $70-79$ & 12 & 24 & 840 & 1824 & 37,5 & 75 & & \\
3 & Cukup & $60-69$ & 16 & & 1048 & & 50 & & (Cukup) & (Baik) \\
4 & Kurang & $<60$ & & & & & & & & \\
\hline
\end{tabular}


Lestari Ambar Sukesti

Peningkatan Kemampuan Berbicara Teks Hortatory Exposition Menggunakan Problem Based Learning Dengan

Presentasi Berbantuan Film

\begin{tabular}{lllllll}
\hline Jumlah & 32 & 32 & 2248 & 2504 & $100 \%$ & $100 \%$
\end{tabular}

Data pada tabel 5 menunjukkan peningkatan rerata nilai kreativitas sebesar 9,13\% dari 69,12 pada siklus I menjadi 78,25 pada siklus II. Prosentase jumlah peserta didik yang mencapai KKM 70 juga meningkat sebesar 50\% dari 50\% pada siklus I menjadi 100\% pada siklus II.

\section{PEMBAHASAN}

Problem Based Learning (PBL) merupakan model pembelajaran yang menitikberatkan pada masalah yang otentik sehingga peserta didik dapat menemukan dan memecahkan masalah yang dihadapinya sendiri dari pengetahuan yang disusunnya sendiri, mengembangkan inkuiri dan keterampilan berpikir tingkat tinggi serta mengembangkan kemandirian dan rasa percaya diri (Arends, 2008). Oleh karena itu model pembelajaran Problem Based Learning (PBL) dianggap sebagai model pembelajaran yang mampu meningkatkan kemampuan berpikir kritis.

Pembelajaran ini bertumpu pada langkah pembelajaran sebagai berikut : 1) adanya konsep dasar yaitu guru menyampaikan pengetahuan dasar yang terdiri dari konsep dasar, instruksi, sumber, koneksi, dan keterampilan yang dibutuhkan dalam mata pelajaran yang akan disajikan; 2) pendefinisian masalah yaitu guru menyampaikan permasalahan lalu peserta didik melakukan curah gagasan di dalam kelompok; 3) pembelajaran mandiri yaitu peserta didik mencari referensi sebagai sumber belajar; 4) pertukaran pengetahuan yaitu peserta didik berdiskusi di dalam kelompoknya untuk menemukan solusi atas permasalahan yang dihadapinya; 5) penilaian yaitu penilaian baik yang berupa pengetahuan, sikap, dan keterampilan.

Model pembelajaran Problem Based Learning (PBL) dengan langkah-langkah tersebut tidak hanya dikhususkan untuk meningkatkan hasil belajar (Safitri, 2009) tetapi dapat juga meningkatkan komunikasi. Meski demikian penggunaan model pembelajaran Problem Based Learning ini tidak sepenuhnya berhasil untuk meningkatkan komunikasi sebagaimana dinyatakan oleh Fatimah (2002) bahwa proses komunikasi masih menunggu arahan dan bimbingan dari dosen karena mahasiswa bersikap pasif yaitu menerima informasi dari dosen (Paulina, 2001).

Dapat dipahami juga bahwa model pembelajaran Problem Based Learning (PBL) dapat meningkatkan sikap berpikir kritis (Fakhriyah, 2014). Dinyatakan oleh Blumhof (2001) bahwa melalui model pembelajaran Problem Based Learning (PBL) dapat meningkatkan kinerja positif untuk mengatur pembelajaran sendiri yang aktif, reaktif, kritis, serta berpikir mendalam 
Lestari Ambar Sukesti

Peningkatan Kemampuan Berbicara Teks Hortatory Exposition Menggunakan Problem Based Learning Dengan

Presentasi Berbantuan Film

dan menyeluruh, dan memungkinkan terjadinya pembelajaran sesuai masalah yang sedang terjadi.

Model pembelajaran PBL dapat meningkatkan keaktifan dan antusiasme peserta didik dalam pembelajaran (Ramadhana, 2018; Sektyawardani, 2017). Penelitian ini juga memiliki relevansi dengan penelitian yang dilakukan oleh Hanafiah (2019) bahwa film memberikan dampak positif terhadap peningkatan keterampilan berbicara bahasa Inggris.

\section{KESIMPULAN DAN SARAN}

Model Pembelajaran PBL dengan presentasi berbantuan film efektif untuk meningkatkan penguasaan materi belajar peserta didik sehingga dapat meningkatkan kompetensi peserta didik dalam berbicara teks hortatory exposition. Peserta didik antusias berbagi ide saat melakukan kegiatan diskusi dalam kelompok untuk membuat garis besar sebelum mengembangkannya menjadi sebuah teks dan presentasi berbantuan film. Situasi dan masalah yang nyata dan kontekstual lebih memudahkan para peserta didik untuk mengelaborasi lebih banyak informasi.

Penggunaan model PBL dengan presentasi berbantuan film memungkinkan peserta didik untuk berpikir tingkat tinggi yaitu berpikir kritis untuk menemukan solusi atas masalah yang diberikan. Peserta didik berani menyampaikan ide-ide tanpa rasa takut ketika bekerja bersama di dalam kelompok. Hal ini menjadikan peserta didik dapat menerima dan menghargai ide-ide dari anggota kelompok.

Dari hasil tes keterampilan berbicara, dapat disimpulkan bahwa penggunaan model pembelajaran PBL menggunakan presentasi berbantuan film dapat meningkatkan keterampilan berbicara peserta didik di samping berkembangnya kreativitas dalam bentuk produk presentasi berbantuan film.

Saran yang dapat disampaikan penulis adalah sebagai seorang guru hendaknya lebih kreatif dan inovatif dalam melakukan proses pembelajaran terutama pada pembelajaran keterampilan berbicara khususnya pada mata pelajaran bahasa Inggris. Banyak strategi yang bisa digunakan agar tujuan pembelajaran keterampilan berbicara dapat mencapai hasil yang optimal.

Strategi pembelajaran keterampilan berbicara seharusnya lebih banyak menekankan pada praktik berbicara itu sendiri baik dalam kegiatan diskusi kelompok maupun presentasi. Melalui PBL dengan presentasi berbantuan film, banyak hal bisa didapat oleh peserta didik berkaitan penumbuhan sikap berpikir kritis dalam mencari dan menemukan solusi atas masalah yang terjadi dalam kehidupan nyata. 
Lestari Ambar Sukesti

Peningkatan Kemampuan Berbicara Teks Hortatory Exposition Menggunakan Problem Based Learning Dengan

Presentasi Berbantuan Film

Teknik ini membutuhkan pengembangan lebih lanjut sehingga penulis menyarankan lebih banyak penelitian pada KD lain untuk membangkitkan minat peserta didik dalam belajar yang selanjutnya dapat meningkatkan hasil belajar maupun keterampilan berbahasa, tidak hanya bahasa Inggris tetapi juga mata pelajaran lainnya.

\section{DAFTAR PUSTAKA}

Arends, R. (2008). Learning to Teach. Yogjakarta: Pustaka Pelajar.

Arikunto, S. (2010). Penelitian Tindakan Kelas. Yogyakarta: Aditya Media.

Blumhof, J., Hall, M., Honeynone, A. (2001). Using Problem Based Learning to Develop to Graduate Skills, dalam Planet Spescial Edition. Case Studies in Problem Based Learning (PBL) from Geography, Earth dan Environmental Science. LTSN. 6-10. UK

Derewianka, B. (1995). Exploring How Text Works. Newtown, NSW: PETA.

Ellis, R. (2008). The Study of Second Language Acquisition (second ed). Oxford: Oxford University Press.

Fakhriyah. (2014). Penerapan Problem Based Learning Dalam Upaya Mengembangkan Kemampuan Berpikir Kritis Mahasiswa. Jurnal Pendidikan IPA Indonesia. JPII 3 (1) (2014) 95-101

Gerot, L. \& Wignell, P. (1994). Making Sense of Functional Grammar. New South Wales: Antipodean Educational Enterprises.

Hanafiah, W. (2019). Peningkatan Keterampilan Berbicara Bahasa Inggris Melalui Media Film. Epigram Vol. 16 No. 2 Oktober 2019.

Hauroni, F. (2015). The Use Of Project-Based Learning In Teaching Analytical Exposition Text To Improve Students' Speaking Skill: A Descriptive Qualitative Research at One of Public Senior High Schools in Bandung. Other thesis, Universitas Pendidikan Indonesia. Iskandarwassid \& Sunendar, D. (2010). Strategi Pembelajaran Bahasa. Bandung: PT. Remaja Rosda Karya Offset.

Kemdikbud (2014). Materi Pelatihan Guru Implementasi Kurikulum 2013 Tahun 2014 Mata Pelajaran Bahasa Inggris SMA.

Mudjiman, H. (2006). Belajar Mandiri. Surakarta: LPP UNS dan UNS Press.

Mukaromah, A. (2011). The Effectiveness of Teaching Hortatory Exposition Text using Video Clip.Thesis. Semarang: UIN. 
Lestari Ambar Sukesti

Peningkatan Kemampuan Berbicara Teks Hortatory Exposition Menggunakan Problem Based Learning Dengan

Presentasi Berbantuan Film

Ningsih, Sri, et al. (2007). Bahasa Indonesia untuk Mahasiswa. Yogyakarta: CV Andi Offset.

Noer, M. (2011). Presentasi Yang Memukau.Jakarta: Yodhia Antariksa.

Nurgiyantoro, B. (2001). Penilaian dalam Pengajaran Bahasa dan Sastra. Yogyakarta: BPEF.

Nurhadi. (2004). Tata Bahasa Pendidikan: Landasan Penyusunan Buku Pelajaran Bahasa. Semarang: IKIP Semarang Press.

Paulina, P., dkk. (2001). Konstruktivisme dalam Pembelajaran. Jakarta: PAUPPAI, Universitas Terbuka.

Pusat Kurikulum, Balitbang Depdiknas. (2004). Pedoman Khusus Pengembangan Instrumen dan Penilaian Ranah Afektif. Jakarta.

Ramadhana, F. (2018). Increasing Students' Speaking Participation Using Problem Based Learning (PBL) and Their Perception toward the Strategy' Ramadhana. Diploma Thesis, Universitas Negeri Malang.

Safitri, M. (2009). Penerapan Model Pembelajaran Problem Based Learning (PBL) untuk Meningkatkan Hasil Belajar Siswa pada Mata Pelajaran IPS Kelas VI SDN Janjangwulung II Kecamatan Puspo Kabupaten Pasuruan. Thesis. UNM.

Sanjaya, W. (2007). Strategi Pembelajaran Berorientasi Standar Proses Pendidikan. Jakarta: Kencana.

Sektyawardani, G. (2017). Pengaruh Metode Problem Based Learning (PBL) terhadap Kemampuan Menulis dan Berbicara Teks Negosiasi Siswa Kelas X di SMA Negeri 3 Purwokerto. Masters Thesis, Universitas Muhammadiyah Purwokerto

Slamet, St. Y. (2008). Peningkatan Keterampilan Berbahasa Indonesia. Surakarta: UNS Press. Susana, A. (2013). Meningkatkan Keterampilan Berbicara Siswa Kelas VIII.A MTs Zainul Bahar melalui Strategi Pembelajaran Kooperatif Tipe Think Pair Share (TPS). Skripsi. Jember: Unej

Sutomo, E. (2007). 9 Presentasi Kreatif dengan PowerPoint 2007. Yogyakarta: Andi Offset

Tarigan, H. G. (2008). Berbicara sebagai Suatu Keterampilan Berbahasa. Bandung: Angkasa Triwahyuni, T. C. \& Kadir, A. (2004). Presentasi Efektif dengan Microsoft Power Point. Yogyakarta: Andi Offset.

Thornburry, S. (1990). How to Teach Speaking. London: Longman.

Triyanto. (2007). Model-model Pembelajaran Inovatif Berorientasi Kontruktivistik. Jakarta: Prestasi Pustaka. 
Lestari Ambar Sukesti

Peningkatan Kemampuan Berbicara Teks Hortatory Exposition Menggunakan Problem Based Learning Dengan Presentasi Berbantuan Film

Wahab, A. A. (2007). Metode dan Model-Model Mengajar. Bandung: Alfabeta.

Yule, G. (1996). Pragmatics. New York: Oxford University Press. 